\title{
MULTIPLICAREA SOIULUI DE MACEȘ CAN PRIN VITROCULTURI
}

\author{
Ciorchină Nina, Roșca I., Sofronii Maria, Cuzmina Elvira \\ Grădina Botanică Națională (Institut) „,Alexandru Ciubotaru”, Chișinău, Republica Moldova \\ e-mail: ninaciorchina@mail.ru
}

Măceșul (Rosa canina) face parte din genul Rosa care include circa 400 de specii răspândite pe larg în zonele temperate şi subtropicale ale Emisferei de Nord. Speciile din genul Rosa L. reprezintă arbuști târâtori, erecți cățărători și semierecți, sunt prezentate de forme agăţătoare serpente şi volubile de diferită lungime.

Importanța culturii. Conținutul de vitamina $\mathrm{C}$ în fructele de măceș este de zece ori mai mare decât în bacele de coacăz-negru și de cincizeci de ori mai mare decât în mere. Miezul fructelor de măceș mai conţine provitamina $\mathrm{A}$ (caroten), vitamina $\mathrm{B}_{2}$ (riboflavină), vitamina $\mathrm{P}$ (citrin), vitamina $\mathrm{K}$, vitamina E. Așadar, putem afirma că măceșul este un rezervor de vitamine pentru organismul uman. Măceșele sunt bogate și în zaharuri, acizi organici, substanțe pectice și tanante, săruri minerale. Introducerea măceșului în cultură va asigura cu vitamine populația tării.

Din sortimentul fără spini fac parte soiurile 'Piros' 1 și 'Piros 2', dar sunt sensibile la secetă şi temperaturi scăzute, ce nu în tocmai corespunde zonei noastre cu clima temperată. Din circa 15 soiuri productive fără spini sau cu spini puțini și de interes economic cu conținut de substanțe biologic active sporit sunt preponderent de proveniența rusă. Atenția noastră a fost atrasă la două soiuri de origine română: 'BRAŞOV-2' - soi omologat în anul 1991 la Staţiunea Montană Cisnădie. Plantele sunt viguroase, productive, rezistente la ger, secetă şi făinare. Din cele două a fost selectat soiul 'CAN', ca fiind caracteristic zonei Republica Moldova.

'CAN' - ICPP Pitești Mărăcineni soi românesc cu tufa viguroasă, de până la 3 m înălțime, cu 5-6 tulpini multianuale crescute din zona bazală. Fructul mare $(5,5 \mathrm{~g})$, forma alungită, culoarea roșieintensă, lucioasă, conţinutul de vitamina C mediu (cca. 580-600 mg\%). Epoca de maturare a fructelor timpurie, la începutul lunii septembrie. Producția $4-5 \mathrm{~kg} / \mathrm{tufă}$.

Speciile măceșului vitaminos pot fi multiplicate generativ și vegetativ. Măceșul, obținut prin metoda generativă, începe să fructifice mai târziu decât cel obținut din multiplicarea vegetativă. Puieții de măceș, obținuți din semințe, începând cu anul 3-4 de viață, se disting printr-o mare rezistență față de condițiile climatice nefavorabile, dar se pronunță puternic descendența puieților, materialul săditor obținut este neuniform. Reeșind din acest fapt, noi am considerat că multiplicarea vegetativă prin vitroculturi este o soluție rezonabilă din mai multe puncte de vedere: material obținut este copie plantei-mama (donor), obținerea materialului săditor la anumit termen în cantități nelimitate, multiplicarea anul împrejur, reducerea simțitoare a costului unei plante, devirozarea și obținerea materialului săditor robust și sănătos. Pentru inoculare a fost utilizat mediul nutritiv Murashige-Skoog (1962) modificat MS 100\% + agar 5 g/l, zaharoză 30 g/l, acid ascorbic 1,0 mg/l, IBA $0,1 \mathrm{mg} / \mathrm{l}$, BAP $0,5 \mathrm{mg} / \mathrm{l}, \mathrm{pH}-5,8$. Pentru iniţiera vitroplantulelor a fost necesare $40-45$ zile, după care vitroplantulele, cu dimensiunea 2,0-2,5 $\mathrm{cm}$ au fost trecute pe alt tip de mediu nutritiv (mediu pentru rizogeneză) cu următoarea componență chimică: MS $100 \%$ + zahăr comercial 30 g/l, acid ascorbic 2 mg/l, IBA $0,1 \mathrm{mg} / \mathrm{l}, \mathrm{pH}-5,8$. Pe această balanță nuritivă mini butașii introduși în mediu se dezvoltă 30-35 de zile, până ating dimensiuni de 11-12 cm și formează rădăcini. Aclimatizarea plantulelor de măceș soiul 'Can' se realizează în 3 etape. Substrat: turba cu pH 5,8-6,0, nisip de râu, sol de gazon, perlit, în proporții 2:1:2:1. 